\title{
Influence of light and temperature cycles on the expression of circadian clock genes in the mussel Mytilus edulis
}

Running head: Mussel circadian rhythms, light \& temperature

Emma C. Chapman ${ }^{1}$, Brodie J. Bonsor ${ }^{2}$, Daniel R. Parsons ${ }^{3}$ and Jeanette M. Rotchell ${ }^{1} *$

${ }^{1}$ Department of Biological and Marine Sciences, University of Hull, Cottingham Road, Hull, HU6 7RX, United Kingdom

${ }^{2}$ Department of Chemistry and Biochemistry, University of Hull, Cottingham Road, Hull, HU6 7RX, United Kingdom

3 Department of Geography, Geology and Environment, University of Hull, Cottingham Road, Hull, HU6 7RX, United Kingdom

\section{Corresponding Author}

*Jeanette M. Rotchell, phone number: +44 (0) 1482 465333, fax number: +44 (0) 1482 465458, e-mail: J.Rotchell@ Hull.ac.uk

Paper type: Primary research

\section{Abstract}

Clock genes and environmental cues regulate essential biological rhythms. The blue mussel, Mytilus edulis, is an ecologically and economically important intertidal bivalve undergoing seasonal reproductive rhythms. We previously identified seasonal expression differences in M. edulis clock genes. Herein, the effects of light/dark cycles, constant darkness, and daily temperature cycles on the circadian expression patterns of such genes are characterised.

Clock genes $C l k, C r y 1, R O R / H R 3, P e r$ and $R e v$-erb/NR1D1, and Timeout-like, show significant mRNA expression variation, persisting in darkness indicating endogenous control. Rhythmic expression was apparent under diurnal temperature cycles in darkness for all except Rev$e r b$. Temperature cycles induced a significant expression difference in the non-circadian clock-associated gene aaNAT. Furthermore, Suppression Subtractive Hybridisation (SSH) was used to identify seasonal genes with potential links to molecular clock function revealed numerous genes meriting further investigation. Understanding the relationship between environmental cues and molecular clocks is crucial in predicting the outcomes of environmental change on fundamental rhythmic processes.

Keywords: Mytilus, bivalve, mollusc, circadian rhythm, clock, light, photoperiod, diurnal, temperature, mRNA

\section{Introduction}

Intertidal habitats are under the influence of multiple fluctuating conditions, a number of which, such as diel day/night cycles, tidal immersion/exposure and annual seasonal progression, are cyclical in nature and can provide reliable environmental cues to inform biological timekeeping. Rhythmic biological processes, producing diverse physiological and behavioural outputs over a wide range of temporal and 
spatial scales, are essential to marine ecosystems (Tessmar-Raible et al., 2011). Common examples include rhythmic locomotor activity (Newcomb et al., 2014), oxygen consumption (Kim et al., 1999), feeding (Houki et al., 2015), reproduction (Wayne, 2001), cell renewal (Zaldibar et al., 2004), nerve impulses (Jacklet, 1969) and gene expression (Connor \& Gracey, 2011).

Endogenous biological rhythms are underpinned by a circadian clock mechanism operating on a sub-cellular level. Clock gene expression, evolved to occur over a $\sim 24 \mathrm{hr}$ period, is regulated by a negative feedback system in which clock proteins inhibit their own expression (Allada et al., 2001; Young \& Kay, 2001). Though able to persist in the absence of environmental cues, synchronisation of these endogenous molecular rhythms by cycling environmental parameters like light and temperature is known as entrainment, and is an essential component of circadian rhythms (Golombek \& Rosenstein, 2010; Dubruille \& Emery, 2008; Rensing \& Ruoff, 2002). Entrainment is considered adaptive and influences the timing of diverse physiological and behavioural processes via clock-output genes (Zhang et al, 2009). Despite the importance of clock genes in regulating endogenous rhythmic processes in diverse phyla, the molecular mechanisms governing timekeeping ability are an understudied aspect of molluscan ecology. Recently emerging studies have characterised clock genes in gastropods (Cook et al., 2018; Duback et al., 2018; Schnytzer et al., 2018; Bao et al., 2017; Constance et al., 2002), cephalopods (HeathHeckman et al., 2013), and bivalves (Perrigault \& Tran, 2017; Sun et al., 2016; Pairett \& Serb, 2013) including mussels (Chapman et al., 2017; Connor \& Gracey, 2011). Blue mussels, Mytilus edulis, are an edible species of commercial importance (FAO, 2018), a biogenic keystone species (Gutiérrez et al., 2003) and are considered early indicators of the effects of climate change (Zippay and Helmuth, 2012). Important rhythmic processes documented in mussels include circadian valve activity (Gnyubkin, 2010), circatidal rhythms of epithelial cell renewal (Zaldibar et al., 2004), seasonal cycles of gametogenesis (Seed, 1969), and both circadian and tidal gene expression patterns with the former being more prevalent (Connor \& Gracey, 2011). Among these rhythmic transcripts are the clock genes Cryl and ROR, which cycle on a circadian basis in the gills of Mytilus californianus (Connor \& Gracey, 2011). In other bivalves, endogenous circadian expression of multiple clock genes occurs in the Pacific oyster Crassostrea gigas (Perrigault \& Tran, 2017; Mat et al., 2016) whereas only weak/non rhythmic clock gene oscillations were apparent in the limpet Cellana rota (Schnytzer et al., 2018). Cryl and Cry 2 are also rhythmically expressed in the head of the squid Euprymna scolopes (Heath-Heckmann et al., 2013). The putative endogenous nature of the blue mussel molecular circadian clock is yet to be investigated.

In addition to their $24 \mathrm{hr}$ periodicity and endogenous nature, circadian rhythms are temperature-compensated, maintaining their periods over a range of constant temperatures (Ruoff, 2004; Rensing et al., 2001). However, both periodic and pulse temperature changes affect molecular clock function directly and indirectly in many organisms by impacting input pathways, molecular mechanisms, amplitude levels, phase shifts and entrainment (Rensing \& Ruoff, 2002). Furthermore, temperature acts as an important cue (zeitgeber) for rhythm entrainment in both vertebrates and invertebrates (Waite et al., 2017; Glaser \& Stanewsky, 2005; Lahiri et al., 2005) with daily temperature cycles of as little as $1-2{ }^{\circ} \mathrm{C}$ able to entrain ectotherms (Rensing \& Ruoff, 2002). Though elevated temperature during exposure at low tide disrupts rhythmicity of genes with circadian and tidal periodicities in mussels (Connor \& Gracey, 2011), the influence of temperature cycles on bivalve clock gene activity is unknown. Wild intertidal blue mussels experiencing natural seasonal photoperiod and temperature shifts, exhibit clock gene expression differences between seasons (Chapman et al., 2017), but the relative importance of light and temperature are yet to be elucidated. In addition, seasonal expression differences in genes involved in gametogenesis, metabolism, stress response and immunity have been documented in mussels (Banni et al., 2011; Ciocan et al., 2011), however there is further scope to investigate seasonally expressed genes with putative links to the molecular clock mechanism. 
The primary purpose of this study was to assess whether M. edulis clock genes (1) exhibit a circadian pattern of mRNA expression under light/dark conditions, (2) have endogenous rhythmicity that persists in constant darkness and (3) are influenced by 24 hr temperature cycles in the absence of light. To address these aims, we conducted a laboratory-based experiment to investigate the mRNA expression patterns of M. edulis clock genes (Clock, Cryl, ROR/HR3, Period, Rev-erb/NR1D1) as well as genes with closely associated clock functions (ARNT/ HIF-1 $\beta$, Timeout-like, aaNAT) under different $24 \mathrm{hr}$ light and temperature cycles. The secondary purpose of this study was to isolate and identify novel seasonal M. edulis genes with putative links to the molecular clock mechanism. A global transcriptomic approach was used to compare seasonal cDNA libraries from wild male and female M. edulis respectively, at standardised stages of gametogenesis. For the first time we reveal the endogenous nature of M. edulis clock gene expression in the mantle tissue and investigate the effect of 24 hr thermocycles on a bivalve molecular clock mechanism. Characterising these underlying mechanisms of circadian regulation is an essential first step in predicting the effects of environmental change on the essential rhythmic processes of this important marine species.

\section{- Materials and Methods}

2.1 Sample collection, acclimation and histology

For the photoperiod/thermocycle experiment, adult M. edulis (mean length \pm SEM, $40.53 \pm 0.25 \mathrm{~mm}$ ), were collected from Filey beach, North Yorkshire, UK (54 $13^{\circ}$ longitude and $0^{\circ} 16^{\prime}$ latitude) during low tide on 24.11.16. Mussels were transferred to the laboratory and divided across 9 aerated aquaria ( $n=56$ in each) containing 30L of 35 ppt artificial seawater (Tropic Marin, Germany). Mussels were acclimated for 10 days to constantly submerged conditions at $9.7 \pm 0.4{ }^{\circ} \mathrm{C}$ (mean $\pm \mathrm{SD}$ ) with a photoperiod of $10 \mathrm{hr}$ light/14 hr dark. Throughout both the acclimation period and the experiment, mussels were fed daily at irregular times with PhytoGreen-M Suspension (Brightwell Aquatics, UK) containing Tetraselmis sp. phytoplankton at a final concentration of $\sim 0.43$ million cells per $\mathrm{mL}$ and $50 \%$ water changes were conducted on alternate days at irregular times. Formalin-preserved mantle tissue from all samples were wax embedded, sectioned $(10 \mu \mathrm{m})$, stained with haematoxylin and eosin, and viewed under the microscope to assess gender and gametogenesis stage according to Seed (1969).

For the seasonal field experiment, M. edulis were collected at low tide from Filey beach during winter 2014, spring 2015 and summer 2015 as described in detail in Chapman et al., (2017). Sexually developing females at gametogenesis stages $\beta$ II to $\beta$ III (Seed, 1969) were randomly selected from the late morning winter and summer sampling time ( $n=7$ each) which differ in photoperiod by $10 \mathrm{hr}$. Sexually developing males at gametogenesis stages $\beta \mathrm{III}$ to $\beta \mathrm{IV}$ (Seed, 1969) were selected at random from late morning winter and spring time-points ( $n=6$ each), with a photoperiod difference of $4.5 \mathrm{hr}$ as insufficient $\beta \mathrm{III} / \beta \mathrm{IV}$ males were obtained in summer to allow a winter/summer comparison.

\subsection{Photoperiod and thermocycle exposures}

To investigate the effects of diel light and temperature cycles, laboratory-acclimated mussels ( $n=168$ per treatment) were exposed for 13 days to one of the following regimes: 10:14 hr light/dark cycles at constant temperature (LD), constant darkness at constant temperature (DD), and constant darkness with thermocycles (DDTC) of 10:14 hr thermophase:cryophase varying by $3.6 \pm 0.2^{\circ} \mathrm{C}$ (mean \pm SD). This diel temperature range is environmentally relevant (Kawai \& Wada, 2007) and the LD regime has previously been used to investigate daily and tidal activity and Cryl expression rhythms in the bivalve $C$.gigas (Mat et al., 2016). Each of the 3 aquaria used per treatment were 
independent and were each continually aerated by two air stones. Abiotic conditions were recorded throughout using a Hi 97500 Portable Luxmeter (Hanna Instruments Ltd, Leighton Buzzard, UK), "ama-digit ad 15th" Electronic Thermometer (Amarell Electronic,

Kreuzwertheim, Germany), a V2 salinity refractometer (TMC, UK), and a 3510 pH Meter (Jenway, Bibby Scientific Limited, Stone, UK). Water parameters were maintained as follows (mean $\pm \mathrm{SD}$ ): water temperature in $\mathrm{LD}$ and $\mathrm{DD}, 9.7 \pm 0.5^{\circ} \mathrm{C}$; water temperature at end of DDTC cryophase, $10.1 \pm 0.4{ }^{\circ} \mathrm{C}$; water temperature at end of DDTC thermophase, $13.7 \pm 0.4^{\circ} \mathrm{C}$; salinity, $35.4 \pm 0.6 \mathrm{ppt}$ and $\mathrm{pH}, 7.8 \pm 0.1$. Thermocycles were controlled by adjusting ambient air temperature in a climate-controlled room to simulate gradual water temperature change.

Zeitgeber times 0 to 10 (ZT 0-10) correspond to the photophase and the thermophase in the LD and DDTC treatments respectively. At the end of the experiment, $n=28$ mussels were sampled from each treatment at each of the 6 time points over the course of a day: ZT 23 (an hour before photophase/thermophase), ZT 1, ZT 5, ZT 9, ZT 11 and ZT 15 (Figure S1). Mantle tissue was dissected and stored in RNAlater® Stabilisation Solution (Thermo Fisher Scientific, Loughborough, UK) at $-80^{\circ} \mathrm{C}$ for molecular analysis and in $10 \%$ formalin solution (Sigma Aldrich, Gillingham, UK) for histological examination.

\subsection{Total RNA isolation and cDNA synthesis}

For the photoperiod/thermocycle experiment, total RNA was extracted from a subset of randomly-selected male mussels from each time-point from each of the treatments $(n=7-9)$ using $10 \mathrm{mg}$ of mantle tissue. Reagents from the High Pure RNA Tissue Kit (Roche, Burgess Hill, UK) were used according to manufacturer's instructions, which included DNase I treatment. RNA concentrations were measured using the Qubit 1.0 Fluorometer (Life Technologies, Paisley, UK) and $180 \mathrm{ng}$ of RNA was used for cDNA synthesis using the Precision Nanoscript2 Reverse Transcription Kit with random nonamer (9 bp oligonucleotide) primers (PrimerDesign, Cambridge, UK).

\subsection{Isolation of clock genes}

Degenerate primers for Per were designed from a nucleotide alignment using sequences from the scallop Mizuhopecten yessoensis (XM_021519834.1) and the oyster $C$.gigas (JH816853.1) (Table S1). $0.5 \mu \mathrm{L}$ of each $10 \mu \mathrm{M}$ primer was used for PCR containing $2.5 \mu \mathrm{L}$ Fisher BioReagent 10X Taq Buffer A (Fisher Scientific, UK), $0.5 \mu \mathrm{L}$ dNTP mix (10 mM each), $0.25 \mu L$ Fisher BioReagents ${ }^{\mathrm{TM}}$ Taq DNA Polymerase (Fisher Scientific, UK), $0.5 \mu \mathrm{L} \mathrm{MgCl}_{2}(25 \mathrm{mM}), 1 \mu \mathrm{L}$ cDNA and molecular-grade water (Fisher Scientific, UK) to a total volume of $25 \mu \mathrm{L}$. Thermal cycling conditions were $94^{\circ} \mathrm{C}$ for $2 \mathrm{~min}$, followed by 35 cycles of $94^{\circ} \mathrm{C}$ for $30 \mathrm{sec}, 45^{\circ} \mathrm{C}$ for $30 \mathrm{sec}$ and $72^{\circ} \mathrm{C}$ for $30 \mathrm{sec}$, with a final extension of $72^{\circ} \mathrm{C}$ for 2 min. $5 \mu \mathrm{L}$ of PCR product was subjected to a second PCR under the same conditions and the resulting band purified from the gel using the Macherey Nagel NucleoSpin Gel and PCR Clean-up Kit (Fisher Scientific, UK) and eluted in $20 \mu \mathrm{L} 5 \mathrm{mM}$ Tris/HCl buffer.

Rev-erb primers (Table S1) were designed from the Mytilus galloprovincialis sequence EF644354.2 (Raingeard et al., 2013) and were tested on M. edulis using a PCR with $5 \mu \mathrm{L} 5 \mathrm{X}$ Herculase II Reaction Buffer (Agilent Technologies, UK), $0.5 \mu \mathrm{L}$ dNTP mix (10 mM each), $0.25 \mu \mathrm{L}$ Herculase II Fusion DNA Polymerase (Agilent Technologies), $0.5 \mu \mathrm{L}$ of each primer $(10 \mu \mathrm{M}), 1 \mu \mathrm{L}$ cDNA and molecular-grade water (Fisher Scientific, UK) to a total volume of $25 \mu \mathrm{L}$. Thermal cycling conditions were $94^{\circ} \mathrm{C}$ for 5 min, followed by 35 cycles of $94^{\circ} \mathrm{C}$ for 30 sec, $55^{\circ} \mathrm{C}$ for $30 \mathrm{sec}$ and $72^{\circ} \mathrm{C}$ for $30 \mathrm{sec}$, with a final extension of $72^{\circ} \mathrm{C}$ for $5 \mathrm{~min}$.

All PCR products were run on $1 \%$ agarose TBE gels stained with Gel Red Nucleic Acid Gel Stain (Cambridge Bioscience, Cambridge, UK) 
and sequenced using the EZ Seq Sanger sequencing service (Macrogen Europe, Amsterdam, The Netherlands). Sequences were edited and aligned using BioEdit (Version 7.0.9.0) and identities were confirmed using blastn/blastx searches against the NCBI GenBank database (https://blast.ncbi.nlm.nih.gov/Blast.cgi). Clk, Cryl, ARNT, Timeout-like, ROR/HR3 and aaNAT have previously been isolated from blue mussels (Chapman et al., 2017).

\subsection{Sequence alignments and phylogenetic analysis}

Multiple species amino acid sequence alignments were created for PER and Rev-erb using Clustal Omega (https://www.ebi.ac.uk/Tools/msa/ clustalo/). For phylogenetic analysis MEGA7, Molecular Evolutionary Genetics Analysis version 7.0 (Kumar et al., 2015), was used for sequence alignment, manual editing and phylogeny construction using maximum likelihood analysis. Sequences selected included those from model species of vertebrates and insects in addition to available marine invertebrate sequences from molluscs and crustaceans. The Jones-Taylor-Thornton (JTT) model and the Nearest Neighbour Interchange (NNI) method for heuristic searches were used. The bootstrap method with 1000 replicates was applied to assess support for the tree with values displayed on nodes.

\section{6 qPCR expression of clock and clock-associated genes}

Real-time qPCR assays were optimised and performed for Clk, Cryl, ROR/HR3, Per, Rev-erb, ARNT, Timeout-like and aaNAT. Relative quantification was performed using $18 S$ and $E F 1$ as reference genes as their suitability for M. edulis qPCR experiments has previously been assessed (Chapman et al., 2017; Cubero-Leon et al., 2012; Ciocan et al., 2011) and their geometric mean expression was not significant between groups $\left(\mathrm{KW}=27.199{ }_{17}, \mathrm{p}=0.0552\right)$. qPCR primers gave reaction efficiencies of $90-110 \%$ (Table $\mathrm{S} 2$ ) in line with the

MIQE guidelines (Bustin et al., 2009). qPCR reactions contained $10 \mu \mathrm{L}$ PrecisionPLUS 2x qPCR MasterMix with SYBR Green for the ICycler (PrimerDesign, Southampton, UK), $7 \mu \mathrm{L}$ molecular-grade water, $2 \mu \mathrm{L}$ primer mix (see Table S2) and $1 \mu \mathrm{L} 1 / 2$ diluted cDNA. Reactions were performed in duplicate on a CFX96 Real Time PCR Detection System (Bio-Rad, Hemel Hempstead, UK) as follows: $95^{\circ} \mathrm{C}$ for $2 \mathrm{~min}$, followed by 40 cycles of $95^{\circ} \mathrm{C}$ for $10 \mathrm{sec}, 60^{\circ} \mathrm{C}$ for $1 \mathrm{~min}$ and $72^{\circ} \mathrm{C}$ for $1 \mathrm{~min}$. Melt peaks were generated at the end of each reaction to confirm primer specificity and template-negative reactions were included for each primer pair on all plates. The data were normalised to the geometric mean of the reference genes using the $2^{-\Delta \mathrm{Ct}}$ version of the comparative $\mathrm{Ct}$ method (Schmittgen and Livak 2008), and presented graphically using Microsoft Excel.

\subsection{Suppression Subtractive Hybridisation (SSH)}

SSH is a molecular technique allowing the identification of mRNAs that are differentially expressed between a pair of sample sets. The SSH approach was used to identify genes that were differentially expressed between (1) winter and summer females ( $\beta$ II/ $\beta$ III) and (2) winter and spring males $(\beta \mathrm{III} / \beta \mathrm{IV})$. Total RNA was extracted and quantified as previously described. RNA integrity was assessed on a $1 \%$ formaldehyde agarose denaturing gel stained with $0.15 \mathrm{ug} / \mathrm{mL}$ ethidium bromide (Invitrogen, UK). Four RNA pools were created (winter females, summer females, winter males, and spring males) with each sample represented at an equal concentration (female pools: $357.1 \mathrm{ng}$, $n=7$; male pools: $416.7 \mathrm{ng}, n=6$ ), totalling $2.5 \mu \mathrm{g}$ RNA. cDNA was synthesised using SMARTer ${ }^{\mathrm{TM}}$ PCR cDNA Synthesis Kit (Clontech, Saint-Germain-en-Laye, France) reagents according to manufacturer's instructions. Forward and reverse-subtracted libraries were created using reagents from the PCR-Select cDNA Subtraction Kit (Clontech, France) and the Advantage 2 PCR Kit (Clontech, France) according to 
the manufacturer's protocols. The differential PCR products were cloned using the Original TA Cloning Kit with pCR 2.1 Vector (Life

Technologies, UK) and chemically competent MAX Efficiency DH10B E. coli cells (Life Technologies, UK). Colonies were screened for inserts by PCR using vector-based primers and reagents from the Nucleospin Plasmid DNA purification Kit (Machery-Nagel, UK) were used to purify plasmids before sequencing with the EZ-seq DNA Sanger sequencing service (Macrogen Europe, The Netherlands). Sequences were edited using Bioedit (version 7.2.5) and identified using BLAST searches against the NCBI nucleotide and protein databases.

Sequences were accepted when E-values, the number of hits expected to be obtained by chance, were $<10^{-5}$.

\section{8 qPCR analysis of seasonal genes}

Six mRNAs identified by SSH were selected for further investigation using real-time qPCR. qPCR reactions were performed as previously described with the exception that assays were prepared as follows: $10 \mu$ L FastStart Universal SYBR Green Master (Rox) (Roche, UK), $7 \mu \mathrm{L}$ molecular-grade water (Fisher Scientific, UK), $1 \mu \mathrm{L}$ of each primer (Table S3) and $1 \mu \mathrm{L}$ of cDNA (derived from $190 \mathrm{ng}$ RNA). qPCR was performed on the same samples used for $\mathrm{SSH}$, supplemented with additional samples at the same gametogenesis stages to increase the sample number to $n=8-11$ per group.

\subsection{Statistical analysis}

Statistical analyses were performed in GraphPad InStat v3 on the normalised expression values. For the photoperiod/thermocycle experiments, one-way Analysis of Variance (ANOVA) was performed for each treatment, followed by the post hoc Tukey-Kramer Multiple Comparisons Test when significance was detected. In instances where the Bartlett's test detected unequal variance, the non-parametric Kruskal-Wallis test was applied, followed by the Dunn's Multiple Comparisons Test when significance was detected. mRNA expression that significantly varied across the 6 time points was considered rhythmic expression. For the seasonal experiment, the data were analysed using unpaired t-tests or the Mann-Whitney Test when appropriate. In all cases, statistical significance was accepted at the $p<0.05$ level.

\section{- $\quad$ Results}

3.1 Isolation of clock genes Per and Rev-erb from M. edulis

A 575 bp partial Per sequence (GenBank accession MH836580) was isolated from M. edulis. The conceptually translated amino acid sequence (blastx) shared $41 \%$ similarity with a period-like isoform from the oyster Crassostrea virginica (XP_022345656.1) and 38\% with sea snail B. gouldiana period (AAK97374.1). Per was subsequently identified in M. galloprovincialis by comparing M. edulis Per against the transcriptome database generated by Moreira et al. (2005), where a 96\% similarity match was obtained with a $3.3 \mathrm{~Kb}$ sequence (Unigene27326). A multiple-species amino acid alignment, showing a PAS domain and the Period C terminal region, indicates relatively low PER sequence homology even among bivalves (Figure S2), as has previously been noted for other bivalve species (Pairett and Serb, 2013). The M. galloprovincialis PER sequence, as the longer of the two Mytilus sequences, was used for phylogenetic analysis. This sequence grouped with other mollusc sequences, particularly bivalves, and showed a greater degree of similarity with other invertebrate PER sequences than with vertebrate PERs (Figure S3).

A 427 bp partial Rev-erb/NR1D1 sequence (MH748543) was also obtained. The conceptually translated sequence shared $96 \%$ amino acid similarity with both M. galloprovincialis NRID1 (ABU89807.2) and NRID2 (ABU89808.2) followed by a 72\% match with C. gigas NR1D 
(AHV90297.1), and contained a DNA-binding domain of Rev-Erb receptor-like (Figure S4). Phylogenetic analysis grouped the Mytilus sequence with other bivalves, closer to other invertebrates groups than vertebrates (Figure S5).

\subsection{Rhythmic clock mRNA expression under LD persists in DD}

Expression patterns of clock and clock-associated genes were investigated in M. edulis exposed to 10:14 hr photocycles (LD) and constant darkness (DD) in parallel. Significant variation in mRNA expression levels were observed under LD conditions for all five of the canonical clock genes investigated: Clk, Cryl, ROR/HR3, Per and Rev-erb (Figure 1 and S6; Table S4). Generally, expression significantly increased in LD after lights on at zeitgeber time (ZT) 0 and then decreased by the end of the photophase at ZT 9 with some cases, Cryl in particular, showing a second peak in expression after the lights on/off transition at ZT11 (Figure 1 and S6). For each of these genes, significant variation was also observed in the absence of environmental light cues under DD with two significant increases in expression, at the start of the subjective day and night respectively, apparent for Clk, Cryl and ROR (Figure 1 and S6; Table S4). For the clock-associated genes, a non-significant trend was detected for $A R N T$ under LD, which was significant under DD with increases in expression at the start of the subjective day and night respectively. Timeout-like exhibited significant variation under LD and DD, peaking at ZT16 during the LD scotophase, and showing peaks during both the subjective day and night under DD (Figure 1 and S6; Table S4). Conversely, aaNAT exhibited constant expression under both LD and DD (Figure 1 and S6; Table S4).

\subsection{Effect of DDTC on rhythmic clock $m R N A$ expression}

The impacts of $3.6 \pm 0.2^{\circ} \mathrm{C}$ (mean $\pm \mathrm{SD}$ ) temperature cycles applied to mussels kept in constant darkness (DDTC) were also assessed in terms of clock and clock-associated gene mRNA expression. For four of the five clock genes investigated, Clk, Cryl, ROR/HR3 and Per, the significant mRNA variation under LD and DD was also apparent under DDTC (Figure 1 and S6; Table S4). However, thermocycles resulted in a loss of significant rhythmicity for Rev-erb (Table S4). For the clock-associated genes, significant daily expression differences were apparent for ARNT and Timeout-like with peak expression occurring in the cryophase in both cases (Figure 1 and S6; Table S4). The constant expression of aaNAT exhibited under both LD and DD was significantly modulated by thermocycles (Table S4); mRNA expression peaked during the mid thermophase, and was lowest immediately after the transition to the cryophase (Figure 1 and S6).

\subsection{Suppression Subtractive Hybridisation analysis}

A total of 40 clones containing successfully ligated plasmids were sequenced from the female SSH cDNA libraries and blastx and blastn searches against the NCBI database revealed the following matches: $37.5 \%$ with known identities and function were suggested to be either up- or downregulated in summer females compared to winter females (Table 1), $12.5 \%$ unnamed sequences, $7.5 \%$ no matches and $42.5 \%$ were duplicate sequences. For males, a total of 18 ligated plasmids were sequenced: $27.7 \%$ matched to sequences with known identities and function which were indicated to be either up- or downregulated in males from spring compared to males from winter (Table 2), $5.5 \%$ matched to unnamed sequences, $27.7 \%$ had no database matches and $38.8 \%$ were duplicate sequences. Of the successfully identified sequences, the majority of matches were to molluscs (Table 1,2).

\section{5 qPCR validation of SSH}

Six target mRNAs isolated during the SSH experiment were selected for qPCR investigation. Transcripts with a range of different 
functions (Tables 1,2) were selected from across the 4 cDNA libraries as follows: PDXK (indicated by SSH to be upregulated in summer females), GTPBP1-like, ABCE1 and Neuroplastin-like (downregulated in SSH summer females), ND4 (upregulated in SSH spring males) and eIF-4A-like (downregulated in SSH spring mussels) (Figure 2). GTPBP1-like expression was significantly lower in the summer compared to the winter (Mann-Whitney: $\mathrm{U}=23.0, p=0.0465$ ), consistent with the SSH findings (Table 1). Significant differences were not detected between seasons for the other genes in this preliminary dataset.

\section{- Discussion}

This study investigated the rhythmic characteristics of the blue mussel molecular circadian clock. The impacts of light and temperature cycles on clock mRNA expression patterns were investigated in a laboratory-based mesocosm experiment. For the first time in the species, we isolated $\mathrm{Per}$ and Rev-erb sequences and examined their diel expression alongside other clock $(C l k, C r y l, R O R / H R 3)$ and clock-associated (ARNT, Timeout-like, aaNAT) genes under $24 \mathrm{hr}$ light/dark cycles (LD), constant darkness (DD) and $24 \mathrm{hr} 3.6^{\circ} \mathrm{C}$ temperature cycles in constant darkness (DDTC). Results indicated rhythmic endogenous expression of clock genes, revealed by persistence of expression variation in the absence of light/dark cues, and the ability of temperature cycles to modulate gene expression patterns in some instances.

\subsection{Effect of photocycles and constant darkness on clock mRNA expression}

Clock genes and their protein complexes interact via negative feedback loops, forming the molecular clock mechanism at the heart of biological timekeeping (Hardin, 2005; Young \& Kay, 2001; Shearman et al., 2000). The single Per homolog present in molluscs (Sun et al., 2016; Constance et al., 2002) was isolated in M. edulis herein and grouped phylogenetically with other molluscan PER sequences (Figure S3). Also isolated was M. edulis Rev-erb (E75) containing the characteristic DNA-binding and ligand-binding domains (Figure S4) and shared most sequence similarity with other mollusc sequences (Figure S5).

The five clock genes investigated ( Clk, Cryl, ROR/HR3, Per and Rev-erb), in addition to Timeout-like, showed significant oscillations in expression under LD cycles (Figure 1 and S6; Table S4). In each case, significant variation in expression persisted under DD (Figure 1 and S6; Table S4), indicative of endogenous circadian control. Expression differences in M. edulis Clk, Cryl and ROR/HR3 were previously detected at comparable daily time-points between seasons (Chapman et al., 2017) but few studies to date have investigated clock gene expression patterns over $24 \mathrm{hr}$ in molluscs. Cryl and ROR exhibit circadian expression in the gills of the mussel M. californianus under LD and tidal conditions, whereas no rhythmicity was apparent for $C l k$ or Bmal (Connor \& Gracey, 2011). In the gills of the oyster $C$. gigas, expression of Clk, Bmal, Per, Tim, Rev-Erb, Cry1, Cry2, pCry and 6-4photolyase varied under LD and was modulated by DD exposure (Perrigault \& Tran, 2017). RNA interference of C. gigas Clk disrupts expression of other clock components including Per, Bmal, Rev-erb, and Cryl (Payton et al., 2017). Cryl in this same species also oscillated under LD but not DD in the adductor muscle, though oscillations under tidal entrainment persisted in constant darkness (Mat et al., 2016).

In non-bivalve molluscs, Per expression in the sea snail Bulla gouldiana was rhythmic in the eye under LD, but constant under DD (Constance et al., 2002). Significant differences in the expression of Clk, Per and Cry genes, showing night-time expression peaks, occur under LD conditions in the brains of the nudibranch Melibe leonina (Duback et al., 2018) whereas clock gene expression rhythms in the limpet Cellana rota did not uphold significance (Schnytzer et al., 2018).. Finally, Cryl and Cry2 have a daily expression pattern in the head of the squid E. scolopes (Heath-Heckman et al., 2013). An increase in clock gene expression at the lights on transition (ZT0) was observed 
during LD for a number of M. edulis clock genes herein (Figure 1 and S6), consistent with findings in $C$. gigas gills (Perrigault \& Tran, 2017). However, second peaks in expression apparent during the subjective night for a number of M. edulis genes under LD (Cryl and Reverb) and DD $(C r y l, C l k$ and $R O R)$ suggest a possible ultradian $(<24 \mathrm{hr})$ rhythm. Hypothetical models of bivalve molecular clocks have been proposed to incorporate elements of both mammalian and insect core interactions (Perrigault \& Tran, 2017; Sun et al., 2016), though functional studies are required to further clarify bivalve clock organisation. The molecular mechanisms by which ultradian rhythms, such 12 hr tidal rhythms, are regulated are also yet to be elucidated.

Clock-associated gene ARNT encodes a bHLH-PAS protein closely related to CYC/BMAL1; both dimerise with melatonin-activated NPAS4 to activate Cryl expression (West et al., 2013). A non-significant trend was apparent in M. edulis ARNT expression under LD which showed significant variation under DD (Figure 1 and S6; Table S4). Significant variation in Timeout-like expression occurred under LD and DD (Figure 1 and S6; Table S4), indicating clock-control. Timeout is the ortholog of mammalian-type Timeless which, in addition to noncircadian roles, has been linked to mammalian clock function (Gotter, 2006; Barnes et al., 2003) and Drosophila light entrainment (Benna et al., 2010). M. edulis Timeout-like peaked during the LD scotophase (ZT15), as is the case in the sea anemone Nematostella vectensis (Reitzel et al., 2010). Finally, aaNAT, which encodes an enzyme involved in rhythmic melatonin production in mammals (Klein, 2007) and some invertebrates (Peres et al., 2014), did not oscillate under LD or DD and does not appear to be under circadian control.

\subsection{Effect of thermocycles on clock mRNA expression}

Acute temperature stress induces and represses a suite of genes across Mytilus species (Lockwood et al., 2015) and can disrupt expression patterns of rhythmic transcripts (Connor \& Gracey, 2011). The effect of diurnal temperature cycles on the expression of bivalve clock genes has not previously been investigated. Though temperature-compensation ensures that the period of clock rhythmicity remains relatively constant over a range of temperatures, the phase of the clock can be reset by temperature cycles and changes (Sweeney \& Hastings, 1960). This includes temperature entrainment of clock gene expression in vertebrates and invertebrates in both terrestrial and aquatic habitats (Glaser \& Stanewsky, 2005; Lahiri et al., 2005; Rensing \& Ruoff, 2002).

Diurnal temperature cycles modulated the expression of two genes herein. Firstly, the significant variation in Rev-erb expression under both LD and DD was no longer apparent under DDTC (Figure 1 and S6; Table S4) indicating disruption. The endogenous nature of Rev-erb found herein is consistent with that of C. gigas; as is the case for vertebrates, Rev-erb is hypothesised to be a core bivalve clock component (Perrigault \& Tran, 2017). Disruption of circadian Rev-erb expression has implications for core clock dynamics as well as its other functions which include lipid metabolism regulation in mice (Cho et al., 2012) and roles in reproduction, moulting and metamorphosis in arthropods (Cruz et al., 2012; Hannas et al., 2010). Rev-Erb $\alpha$ also provides a link between circadian and themogeneic processes in mice (Gerhart-Hines et al., 2013). Secondly, aaNAT expression varied over $24 \mathrm{hr}$ under DDTC, peaking during the thermophase (Figure 1; Table S4), but expression was constant under both LD and DD indicating a clock-independent response to temperature. This is consistent with previous findings that this non-vertebrate version of the gene is involved in more ancestral functions such as detoxification (Pavlicek et al., 2010), contrasting with the rhythmically-expressed vertebrate form essential to melatonin synthesis (Klein, 2007). Rhythmic melatonin production does occur in molluscs (Mũnoz et al., 2011; Abran et al., 1994) but any links to biological timekeeping require further investigation.

The mussel clock genes that exhibited variable expression under both LD and DD also showed significant variation in expression under DDTC (Figure 1 and S6; Table S4) indicating that the oscillations were not disrupted by thermocycles. Variation in ARNT expression also occurred under both DD and DDTC (Figure 1 and S6; Table S4). In the sea snail Haliotis diversicolor, ARNT (HIF-1 $\beta$ ) expression in the 
gills and hemocyctes was not affected by $3{ }^{\circ} \mathrm{C}$ heat shock, though the expression of $\mathrm{HIF}-1 \alpha$, encoding the second subunit of the heterdimeric complex, was significantly elevated (Cai et al., 2014). HIF-1 $\alpha$ links the circadian clock with the hypoxic signalling pathway in vertebrates via core clock genes (Peek et al., 2017; Egg et al., 2013). In other species, temperature affects further aspects of circadian regulation. Sensitivity of the Drosophila clock to temperature results from alternative 3' splicing of Per and Tim mRNAs in the untranslated regions, resulting in phase advancement of the clock at low temperatures (Helfrich-Förster et al., 2018; Dubruille \& Emery, 2008). Temperature input pathways are therefore able to affect multiple levels of molecular clock organisation from transcription and translation to epigenetic modifications and protein degradation (Stevenson, 2018; Rensing \& Ruoff, 2009). Differences between species in sensitivity of the molecular clock to temperature are considered a factor in allowing radiations into different climates (Helfrich-Förster et al., 2018; Rivas et al., 2018). Further investigation is required to determine the potentially synergistic effects of combined environmental stressors on the circadian functioning of M. edulis and other bivalves and functional studies will be key in determining associated changes in cellular function.

\subsection{Identification of potential seasonal candidate genes}

The success rate for cDNA sequence identification from the SSH approach was $31.7 \%$ for the female experiment and $27.7 \%$ for males, consistent with the 22-53\% success rate in similar bivalve experiments (de Cerio et al., 2013; Ciocan et al., 2012; Ciocan et al., 2011; Yang et al., 2012). As qPCR only validated one of the six genes tested (Figure 2), further evidence is required to establish seasonality in the isolated transcripts. However, this preliminary dataset enabled the identification of a number of genes which may have potential as candidate genes in future investigations into seasonal expression differences in female and male mussels (Table 1,2).

Genes indicated by SSH to be potentially differentially expressed in females between winter and summer at the same time of day are involved in multiple processes including signal transduction (HSP90-1, calmodulin), metabolic enzymatic processes (PDXK), cell adhesion (Neuroplastin-like, hemicentin), ribosome biogenesis (GTPBP1-like, ABCE1), energy metabolism (ATP synthase lipid-binding protein, mitochondrial-like; MT-CO2), cilia formation (CEP131), protein cleavage ( $\beta$-MPP), phosphorylation (TESK1) and metabolism (Chitinasel chitotriosidase-like) (Table 1). Some encode proteins that interact with the molecular clock mechanism; HSP90 regulates mammalian BMAL1 protein levels (Schneider et al., 2014), calmodulin is a multifunctional messenger protein involved in phototransduction in Drosophila (Hardie, 2001), and GTPBP1 is involved in regulating mRNA degradation, including that of aaNAT which regulates circadian melatonin production in mammals (Woo et al., 2011). The mRNA transcripts indicated by SSH to be potentially differentially expressed in males between winter and spring were involved in cytoskeleton processes (beta-tubulin, actin), the electron transport chain (ND4) protein synthesis (eIF-4A-like) and chitin metabolism (chitinase/chitotriosidase-like) (Table 2). Chitinases, which are involved in digestion and shell-remodelling processes, show seasonal expression differences in M. galloprovincialis (Banni et al., 2011).

\subsection{Conclusion}

This study investigated the effect of $24 \mathrm{hr}$ light and temperature cycles on M. edulis clock gene expression patterns to increase understanding of how abiotic factors inform biological timekeeping in bivalves. We conclude that the canonical clock genes investigated exhibited endogenous expression in the mantle tissue of blue mussels, with significant variability in mRNA expression persisting under diurnal temperature cycles for all but one (Figure 1 and S6; Table S4). Thermocycles modulated the variable expression of clock gene Rev-erb to 
constant levels and conversely induced significant variation in the otherwise constantly expressed gene aaNAT (Figure 1 and S6; Table S4). Though further investigations are required to clarify the interactions comprising the mussel molecular clock mechanism, it is clear that clock genes play a vital role in regulating the timing of essential rhythmic processes in marine organisms and investigating their responses to environmental inputs is highly relevant to dynamic intertidal habitats in a changing marine environment.

\section{Acknowledgements}

The authors wish to acknowledge Dr Rose Wilcox for assistance with sample collection and Mr David O’Neill for assistance with aquaria maintenance and sample dissection.

\section{Conflict of Interest Statement}

The authors declare that there is no conflict of interest. This research received no specific grant from any funding agency in the public, commercial, or not-for-profit sectors.

\section{Supporting Information}

Primers used for gene isolation and RT-qPCR analyses are provided as additional tables and multiple-species amino acid alignments for Reverb and PER are provided as additional figures.

\section{References}

Abran, D., Anctil, M., and Ali, M. A. (1994). Melatonin activity rhythms in eyes and cerebral ganglia of Aplysia californica. Gen Comp Endocrinol, 96(2), 215-222.

Allada, R., Emery, P., Takahashi, J. S., and Rosbash, M. (2001). Stopping time: the genetics of fly and mouse circadian clocks. Annu Rev Neurosci, 24(1), 1091-1119.

Andreou, A.Z. and Klostermeier, D. (2013). The DEAD-box helicase eIF4A: paradigm or the odd one out? RNA Biol, 10(1), 19-32. Banni, M., Negri, A., Mignone, F., Boussetta, H., Viarengo, A. and Dondero, F. (2011). Gene expression rhythms in the mussel Mytilus galloprovincialis (Lam.) across an annual cycle. PLoS One, 6(5), e18904.

Bao, Y., Xu, F., and Shimeld, S. M. (2017). Phylogenetics of lophotrochozoan bHLH genes and the evolution of lineage-specific gene duplicates. Genome Biol Evol, 9(4), 869-886.

Barnes, J. W., Tischkau, S. A., Barnes, J. A., Mitchell, J. W., Burgoon, P. W., Hickok, J. R., and Gillette, M. U. (2003). Requirement of mammalian Timeless for circadian rhythmicity. Science, 302(5644), 439-442.

Benna, C., Bonaccorsi, S., Wülbeck, C., Helfrich-Förster, C., Gatti, M., Kyriacou, C. P., Costa, R. and Sandrelli, F. (2010). Drosophila timeless 2 is required for chromosome stability and circadian photoreception. Curr Biol, 20(4), 346-352.

Bustin, S. A., Benes, V., Garson, J. A., Hellemans, J., Huggett, J., Kubista, M., Mueller, R., Nolan, T., Pfaffl, M.W., Shipley, G.L. and Vandesompele, J. (2009). The MIQE guidelines: minimum information for publication of quantitative real-time PCR experiments. Clin Chem, 55(4), 611-622.

Chapman, E. C., O’Dell, A. R., Meligi, N. M., Parsons, D. R., and Rotchell, J. M. (2017). Seasonal expression patterns of clock-associated genes in the blue mussel Mytilus edulis. Chronobiol Int, 34(9), 1300-1314. 
Cho, H., Zhao, X., Hatori, M., Ruth, T. Y., Barish, G. D., Lam, M. T., Chong, L.W., DiTacchio, L., Atkins, A.R., Glass, C.K. and Liddle, C. (2012). Regulation of circadian behaviour and metabolism by REV-ERB- $\alpha$ and REV-ERB- $\beta$. Nature, 485(7396), 123.

Ciocan, C. M., Cubero-Leon, E., Minier, C., and Rotchell, J. M. (2011). Identification of reproduction-specific genes associated with maturation and estrogen exposure in a marine bivalve Mytilus edulis. PLoS One, 6(7), e22326.

Ciocan, C.M., Cubero-Leon, E., Peck, M.R., Langston, W.J., Pope, N., Minier, C. and Rotchell, J.M. (2012). Intersex in Scrobicularia plana: transcriptomic analysis reveals novel genes involved in endocrine disruption. Envi Sci \& Tech, 46(23), 12936-12942.

Connor, K. M., and Gracey, A. Y. (2011). Circadian cycles are the dominant transcriptional rhythm in the intertidal mussel Mytilus californianus. Proc Natl Acad Sci USA, 16110-16115.

Constance, C. M., Green, C. B., Tei, H., and Block, G. D. (2002). Bulla gouldiana period exhibits unique regulation at the mRNA and protein levels. J Biol Rhythms, 17(5), 413-427.

Cook, G. M., Gruen, A. E., Morris, J., Pankey, M. S., Senatore, A., Katz, P. S., Watson III, W.H. and Newcomb, J. M. (2018). Sequences of Circadian Clock Proteins in the Nudibranch Molluscs Hermissenda crassicornis, Melibe leonina, and Tritonia diomedea. Biol Bull, 234(3), 207-218.

Craft, J.A., Gilbert, J.A., Temperton, B., Dempsey, K.E., Ashelford, K., Tiwari, B., Hutchinson, T.H. and Chipman, J.K. (2010).

Pyrosequencing of Mytilus galloprovincialis cDNAs: tissue-specific expression patterns. PLoS One, 5(1), e8875.

Cruz, J., Mane-Padros, D., Zou, Z., and Raikhel, A. S. (2012). Distinct roles of isoforms of the heme-liganded nuclear receptor E75, an insect ortholog of the vertebrate Rev-erb, in mosquito reproduction. Mol Cell Endocrinol, 349(2), 262-271.

Cubero-Leon, E., Ciocan, C. M., Minier, C., and Rotchell, J. M. (2012). Reference gene selection for qPCR in mussel, Mytilus edulis, during gametogenesis and exogenous estrogen exposure. Environ Sci Pollut R, 19(7), 2728-2733.

de Cerio, O.D., Hands, E., Humble, J., Cajaraville, M.P., Craft, J.A. and Cancio, I., (2013). Construction and characterization of a forward subtracted library of blue mussels Mytilus edulis for the identification of gene transcription signatures and biomarkers of styrene exposure. Mar Pol Bull, 71(1-2), 230-239.

De Grassi, A., Lanave, C. and Saccone, C. (2006). Evolution of ATP synthase subunit c and cytochrome c gene families in selected Metazoan classes. Gene, 371(2), 224-233.

Duback, V. E., Pankey, M. S., Thomas, R. I., Huyck, T. L., Mbarani, I. M., Bernier, K. R., Cook, G.M., O'Dowd, C.A., Newcomb, J.M. and Watson III, W. H. (2018). Localization and expression of putative circadian clock transcripts in the brain of the nudibranch Melibe leonina. Comp Biochem Physiol A Mol Integr Physiol, 223, 52-59.

Dubruille, R., and Emery, P. (2008). A plastic clock: how circadian rhythms respond to environmental cues in Drosophila. Mol Neurobiol, 38(2), 129-145.

Egg, M., Köblitz, L., Hirayama, J., Schwerte, T., Folterbauer, C., Kurz, A., Fiechtner, B., Möst, M., Salvenmoser, W., Sassone-Corsi, P. and Pelster, B. (2013). Linking oxygen to time: the bidirectional interaction between the hypoxic signalling pathway and the circadian clock. Chronobiol Int, 30(4), 510-529.

Food and Agriculture Organization of the United Nations (FAO). (2018) Global aquaculture production online query. http://www.fao.org/ fishery/statistics/global-aquaculture-production/query/en

Gakh, O., Cavadini, P. and Isaya, G. (2002). Mitochondrial processing peptidases. BBA-Mol Cell Res, 1592(1), 63-77.

García-Horsman, J.A., Barquera, B., Rumbley, J., Ma, J. and Gennis, R.B. (1994). The superfamily of heme-copper respiratory oxidases. J 
Bacteriol, 176(18), 5587.

Gerhart-Hines, Z., Feng, D., Emmett, M. J., Everett, L. J., Loro, E., Briggs, E. R., Bugge, A., Hou, C., Ferrara, C., Seale, P. and Pryma, D. A. (2013). The nuclear receptor Rev-erb $\alpha$ controls circadian thermogenic plasticity. Nature, 503(7476), 410.

Glaser, F. T., and Stanewsky, R. (2005). Temperature synchronization of the Drosophila circadian clock. Curr Biol, 15(15), 1352-1363. Gnyubkin, V. F. (2010). The circadian rhythms of valve movements in the mussel Mytilus galloprovincialis. Russ J Mar Biol, 36(6), 419-428.

Golombek, D. A., and Rosenstein, R. E. (2010). Physiology of circadian entrainment. Physiol Rev, 90(3), 1063-1102.

Gotter, A. L. (2006). A Timeless debate: resolving TIM's noncircadian roles with possible clock function. Neuroreport, 17(12), 1229-1233. Gutiérrez, J. L., Jones, C. G., Strayer, D. L., and Iribarne, O. O. (2003). Mollusks as ecosystem engineers: the role of shell production in aquatic habitats. Oikos, 101(1), 79-90.

Hall, E.A., Keighren, M., Ford, M.J., Davey, T., Jarman, A.P., Smith, L.B., Jackson, I.J. and Mill, P. (2013). Acute versus chronic loss of mammalian Azi1/Cep131 results in distinct ciliary phenotypes. PLoS Genet, 9(12), e1003928.

Hannas, B. R., Wang, Y. H., Baldwin, W. S., Li, Y., Wallace, A. D., and LeBlanc, G. A. (2010). Interactions of the crustacean nuclear receptors HR3 and E75 in the regulation of gene transcription. Gen Comp Endocrinol, 167(2), 268-278.

Hardie, R.C., 2001. Phototransduction in Drosophila melanogaster. J Exp Biol, 204(20), 3403-3409.

Hardin, P. E. (2005). The circadian timekeeping system of Drosophila. Curr Biol, 15(17), R714-R722.

Heath-Heckman, E. A., Peyer, S. M., Whistler, C. A., Apicella, M. A., Goldman, W. E., and McFall-Ngai, M. J. (2013). Bacterial

bioluminescence regulates expression of a host cryptochrome gene in the squid-Vibrio symbiosis. MBio, 4(2), e00167-13

Houki, S., Kawamura, T., Irie, T., Won, N. I., and Watanabe, Y. (2015). The daily cycle of siphon extension behavior in the Manila clam controlled by endogenous rhythm. Fisheries Sci, 81(3), 453-461.

Jacklet, J. W. (1969). Circadian rhythm of optic nerve impulses recorded in darkness from isolated eye of Aplysia. Science, 164(3879), $562-563$.

Kawai, Y., and Wada, A. (2007). Diurnal sea surface temperature variation and its impact on the atmosphere and ocean: A review. J Oceanogr, 63(5), 721-744.

Keeling, P.J. and Doolittle, W.F. (1996). Alpha-tubulin from early-diverging eukaryotic lineages and the evolution of the tubulin family. Mol Biol Evol, 13(10), 1297-1305.

Kim, W. S., Huh, H. T., Lee, J. H., Rumohr, H., and Koh, C. H. (1999). Endogenous circatidal rhythm in the Manila clam Ruditapes philippinarum (Bivalvia: Veneridae). Mar Biol, 134(1), 107-112.

Klein, D. C. (2007). Arylalkylamine N-acetyltransferase:“the Timezyme”. J Biol Chem, 282(7), 4233-4237.

Kumar, S., Stecher, G., and Tamura, K. (2016). MEGA7: molecular evolutionary genetics analysis version 7.0 for bigger datasets. Mol Biol Evol, 33(7), 1870-1874.

Lahiri, K., Vallone, D., Gondi, S. B., Santoriello, C., Dickmeis, T., and Foulkes, N. S. (2005). Temperature regulates transcription in the zebrafish circadian clock. PLoS Biol, 3(11), e351.

Li, S., Xie, L., Zhang, C., Zhang, Y., Gu, M. and Zhang, R. (2004). Cloning and expression of a pivotal calcium metabolism regulator: calmodulin involved in shell formation from pearl oyster (Pinctada fucata). Comp Biochem Phys B, 138(3), $235-243$.

Lockwood, B. L., Connor, K. M., and Gracey, A. Y. (2015). The environmentally tuned transcriptomes of Mytilus mussels. J Exp Biol, 
218(12), 1822-1833.

Mat, A. M., Perrigault, M., Massabuau, J. C., and Tran, D. (2016). Role and expression of cryl in the adductor muscle of the oyster Crassostrea gigas during daily and tidal valve activity rhythms. Chronobiol Int, 33(8), 949-963.

Meng, L., Zhu, Y., Zhang, N., Liu, W., Liu, Y., Shao, C., Wang, N. and Chen, S. (2014). Cloning and characterization of tesk1, a novel spermatogenesis-related gene, in the tongue sole (Cynoglossus semilaevis). PloS One, 9(10), e107922.

Mitchison, T.J. and Cramer, L.P. (1996). Actin-based cell motility and cell locomotion. Cell, 84(3), 371-379.

Moreira, R., Pereiro, P., Canchaya, C., Posada, D., Figueras, A., and Novoa, B. (2015). RNA-Seq in Mytilus galloprovincialis: comparative transcriptomics and expression profiles among different tissues. BMC genom, 16(1), 728.

Muñoz, J. L., Patino, M. A. L., Hermosilla, C., Conde-Sieira, M., Soengas, J. L., Rocha, F., and Míguez, J. M. (2011). Melatonin in octopus (Octopus vulgaris): tissue distribution, daily changes and relation with serotonin and its acid metabolite. J. Comp. Physiol. A, 197(8), 789-797.

Newcomb, J. M., Kirouac, L. E., Naimie, A. A., Bixby, K. A., Lee, C., Malanga, S., Raubach, M. and Watson III, W. H. (2014). Circadian rhythms of crawling and swimming in the nudibranch mollusc Melibe leonina. Biol Bull, 227(3), 263-273.

Owczarek, S. and Berezin, V. (2012). Neuroplastin: cell adhesion molecule and signaling receptor. Int J Biochem Cell, 44(1), 1-5.

Pairett, A. N., and Serb, J. M. (2013). De novo assembly and characterization of two transcriptomes reveal multiple light-mediated functions in the scallop eye (Bivalvia: Pectinidae). PloS One, 8(7), e69852.

Pavlicek, J., Sauzet, S., Besseau, L., Coon, S. L., Weller, J. L., Boeuf, G., Gaildrat, P., Omelchenko, M.V., Koonin, E.V., Falcón, J and Klein, D. C. (2010). Evolution of AANAT: expansion of the gene family in the cephalochordate amphioxus. BMC Evol Biol, $10(1), 154$.

Payton, L., Perrigault, M., Bourdineaud, J. P., Marcel, A., Massabuau, J. C., and Tran, D. (2017). Trojan horse strategy for non-invasive interference of clock gene in the oyster Crassostrea gigas. Mar Biotechnol, 19(4), 361-371.

Peek, C. B., Levine, D. C., Cedernaes, J., Taguchi, A., Kobayashi, Y., Tsai, S. J., Bonar, N.A., McNulty, M.R., Ramsey, K.M. and Bass, J. (2017). Circadian clock interaction with HIF1 $\alpha$ mediates oxygenic metabolism and anaerobic glycolysis in skeletal muscle. Cell Metab, 25(1), 86-92.

Peres, R., Amaral, F. G., Marques, A. C., and Neto, J. C. (2014). Melatonin production in the sea star Echinaster brasiliensis

(Echinodermata). Biol Bull, 226(2), 146-151.

Perrigault, M., and Tran, D. (2017). Identification of the molecular clockwork of the oyster Crassostrea gigas. PloS One, 12(1), e0169790.

Picard, D. (2002). Heat-shock protein 90, a chaperone for folding and regulation. Cell Mol Life Sci. 59(10), $1640-1648$.

Pisarev, A.V., Skabkin, M.A., Pisareva, V.P., Skabkina, O.V., Rakotondrafara, A.M., Hentze, M.W., Hellen, C.U. and Pestova, T.V. (2010).

The role of ABCE1 in eukaryotic posttermination ribosomal recycling. Mol Cell, 37(2), 196-210.

Raingeard, D., Bilbao, E., Cancio, I., and Cajaraville, M. P. (2013). Retinoid X receptor (RXR), estrogen receptor (ER) and other nuclear receptors in tissues of the mussel Mytilus galloprovincialis: cloning and transcription pattern. Comp Biochem Physiol A Mol Integr Physiol, 165(2), 178-190.

Reitzel, A. M., Behrendt, L., and Tarrant, A. M. (2010). Light entrained rhythmic gene expression in the sea anemone Nematostella vectensis: the evolution of the animal circadian clock. PLoS One, 5(9), e12805.

Rensing, L., Meyer-Grahle, U., and Ruoff, P. (2001). Biological timing and the clock metaphor: oscillatory and hourglass mechanisms. Chronobiol. Int, 18(3), 329-369. 
Rensing, L., and Ruoff, P. (2002). Temperature effect on entrainment, phase shifting, and amplitude of circadian clocks and its molecular bases. Chronobiol. Int, 19(5), 807-864.

Roenneberg, T., \& Merrow, M. (2005). Circadian clocks - the fall and rise of physiology. Nat Rev Mol Cell Biol, 6(12), 965.

Ruoff, P. (2004). Temperature-Compensation in Biological Clocks: Models and Experiments. In Function and Regulation of Cellular Systems (pp. 19-29). Birkhäuser, Basel.

Schibler, U. (2005). The daily rhythms of genes, cells and organs: Biological clocks and circadian timing in cells. EMBO Rep, 6(S1), S9-

S13.

Schmittgen, T.D. and Livak, K.J. (2008). Analyzing real-time PCR data by the comparative CT method. Nat Protoc, 3(6), 1101.

Schneider, R., Linka, R.M. and Reinke, H. (2014). HSP90 affects the stability of BMAL1 and circadian gene expression. J Bio Rhythym, 29(2), .87-96.

Schnytzer, Y., Simon-Blecher, N., Li, J., Ben-Asher, H. W., Salmon-Divon, M., Achituv, Y., Hughes, M.E. and Levy, O. (2018). Tidal and diel orchestration of behaviour and gene expression in an intertidal mollusc. Sci Rep, 8(1), 4917.

Seed, R. (1969). The ecology of Mytilus edulis L.(Lamellibranchiata) on exposed rocky shores. Oecologia, 3(3-4), 277-316.

Shearman, L. P., Sriram, S., Weaver, D. R., Maywood, E. S., Chaves, I., Zheng, B., Kume, K., Lee, C.C., Hastings, M.H. and Reppert, S. M. (2000). Interacting molecular loops in the mammalian circadian clock. Science, 288(5468), 1013-1019.

Stevenson, T. J. (2018). Epigenetic regulation of biological rhythms: an evolutionary ancient molecular timer. Trends Genet, 34(2), 90-100.

Sun, X. J., Zhou, L. Q., Tian, J. T., Liu, Z. H., Wu, B., Dong, Y. H., Yang, A.G. and Ma, W. M. (2016). Transcriptome survey of phototransduction and clock genes in marine bivalves. Gen Mol Res, 15(4).

Sweeney, B. M., and Hastings, J. W. (1960). Effects of temperature upon diurnal rhythms. In Cold Spring Harbor symposia on quantitative biology (Vol. 25, pp. 87-104). Cold Spring Harbor Laboratory Press.

Taanman, J.W. (1999). The mitochondrial genome: structure, transcription, translation and replication. BBA-Mol Cell Res, 1410(2), 103-123.

Tessmar-Raible, K., Raible, F., and Arboleda, E. (2011). Another place, another timer: marine species and the rhythms of life. Bioessays, 33(3), 165-172.

Van Eldik, L., Van Eldik, L.J. and Watterson, D.M. eds. (1998). Calmodulin and signal transduction. Gulf Professional Publishing.

Waite, H. R., Sanchez, K. G., and Forward Jr, R. B. (2017). Entrainment of the circadian rhythm in larval release of the crab Dyspanopeus sayi by temperature cycles. Mar Freshw Behav Phy, 50(1), 41-54.

Wayne, N. L. (2001). Regulation of seasonal reproduction in mollusks. J Biol Rhythms, 16(4), 391-402.

West, A., Dupré, S. M., Yu, L., Paton, I. R., Miedzinska, K., McNeilly, A. S., Davis, J.R.E., Burt, D.W. and Loudon, A. S. I. (2013). Npas4 is activated by melatonin, and drives the clock gene Cryl in the ovine pars tuberalis. Mol Endocrinol, 27(6), 979-989.

Woo, K.C., Kim, T.D., Lee, K.H., Kim, D.Y., Kim, S., Lee, H.R., Kang, H.J., Chung, S.J., Senju, S., Nishimura, Y. and Kim, K.T., 2011. Modulation of exosome-mediated mRNA turnover by interaction of GTP-binding protein 1 (GTPBP1) with its target mRNAs. FASEB J, 25(8), 2757-2769.

Xu, X., Xu, M., Zhou, X., Jones, O.B., Moharomd, E., Pan, Y., Yan, G., Anthony, D.D. and Isaacs, W.B. (2013). Specific structure and unique function define the hemicentin. Cell Biosci, 3(1), 27. 
Yang, Z., Wu, H. and Li, Y. (2012). Toxic effect on tissues and differentially expressed genes in hepatopancreas identified by suppression subtractive hybridization of freshwater pearl mussel (Hyriopsis cumingii) following microcystin-LR challenge. Env Tox, 27(7), 393-403. Young, M. W. (2000). Life's 24-hour clock: molecular control of circadian rhythms in animal cells. Trends Biochem Sci, 25(12), 601-606. Young, M. W., and Kay, S. A. (2001). Time zones: a comparative genetics of circadian clocks. Nature Rev Genet, $2(9), 702$.

Zaldibar, B., Cancio, I., and Marigómez, I. (2004). Circatidal variation in epithelial cell proliferation in the mussel digestive gland and stomach. Cell Tissue Res, 318(2), 395-402.

Zhang, E. E., Liu, A. C., Hirota, T., Miraglia, L. J., Welch, G., Pongsawakul, P. Y., Liu, X., Atwood, A., Huss III, J.W., Janes, J. and Su, A. I. (2009). A genome-wide RNAi screen for modifiers of the circadian clock in human cells. Cell, 139(1), 199-210.

Zhao, W., Chen, L., Qin, J., Wu, P., Zhang, F., Li, E. and Tang, B. (2011). MnHSP90 cDNA characterization and its expression during the ovary development in oriental river prawn, Macrobrachium nipponense. Mol Biol Rep, 38(2), 1399-1406.

\section{List of Figure and Table Legends}

Figure 1. Influence of photocycles and thermocycles on the daily variation of mRNA expression of clock and clock-associated genes in $M$. edulis male mantle tissue. Mean expression data, normalised to reference genes $18 S$ and $E F 1$, are plotted \pm SEM; $n=5-9$. Significance denoted by $* \mathrm{p}<0.05$, ** $\mathrm{p}<0.01$ and $* * * \mathrm{p}<0.001$ with adjacent numbers in parentheses referring to significance from the time-points as follows: (1) ZT 23, (2) ZT 1, (3) ZT 5, (4) ZT 9, (5) ZT 11, (6) ZT 15 . Abbreviations: LD, light/dark; DD, dark/dark; DDTC, dark/dark with $\sim 3.5{ }^{\circ} \mathrm{C}$ thermocycles. Unshaded areas represent photophase, light shading represents darkness and heavy shading represents a thermophase during darkness.

Figure 2. mRNA expression of a subset of transcripts identified by $\mathrm{SSH}$ as potentially differentially expressed between seasons in female (PDXK, GTPBP1-like, ABCE1, Neuroplastin) and male (ND4, eIF-4A-like) M. edulis gonads. Mean data \pm SEM. Units are arbitrary. $*$ denotes significance at $p<0.05$ level.

Table 1 mRNAs indicated by SSH to be potentially differentially expressed between summer and winter in the gonads of female M. edulis, at sexual development stages $\beta$ II to $\beta$ III. Sequences shown gave NCBI database matches to sequences of known identities. * blastn nucleotide search, all other results are from a blastx search.

Table 2. mRNAs indicated by SSH to be potentially differentially expressed between winter and spring in gonads of male M. edulis, at sexual development stages $\beta$ III to $\beta I V$. Sequences shown gave NCBI database matches to sequences of known identities. All are from blastx searches.

Fig. 1.

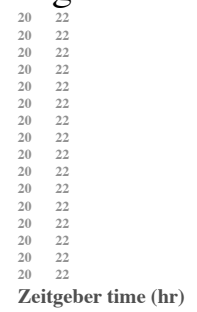




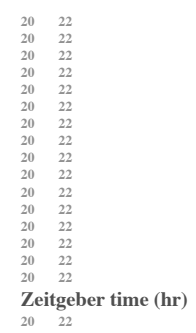

${ }^{20}{ }^{22}$ Zeitgeber time (hr) Zeitgeber time (hr)

DDTC

DDTC

Clk

Cry11

Cry11

Per

Per

LD

LD

DD

DD

ROR/HR3

ROR/HR3

Rev-Erb

Rev-Erb

ARNT

ARNT 
202
20
22
20
20
20
20
20
22
DDTC
DDT

DDTC

Timeout-like

Timeout-like

aaNAT

aaNAT

LD

LD

DD

DD

${ }^{20} \quad{ }^{22}$

Zeitgeber time (hr)

Zeitgeber time (hr)

Zeitgeber time (hr)

${ }^{20}{ }^{22}$ Zeitgeber time (hr)

Zeitgeber time (hr)

Fig. 2 
Table 1

\begin{tabular}{|c|c|c|c|c|c|c|c|}
\hline $\begin{array}{l}\text { Clone accession } \\
\text { number }\end{array}$ & Length (bp) & Identity & Species match & $\begin{array}{l}\text { Result accession } \\
\text { number }\end{array}$ & e-value & Function & Reference(s) \\
\hline \multicolumn{8}{|c|}{$\begin{array}{l}\text { Up-regulated in female summer solstice samples } \\
\text { (compared to winter solstice) }\end{array}$} \\
\hline \multicolumn{8}{|c|}{ Signal transduction } \\
\hline JZ970419 & 222 & $\begin{array}{l}\text { Heat shock } \\
\text { protein } 90 \\
(H S P 90-1)\end{array}$ & $\begin{array}{l}\text { M. } \\
\text { galloprovincialis }\end{array}$ & CAJ85741.1 & $2 e-29$ & $\begin{array}{l}\text { - Molecular } \\
\text { chaperone } \\
\text { - Signal } \\
\text { transduction } \\
\text { - Circadian clock } \\
\text { interactions } \\
\quad \text { with BMAL1 }\end{array}$ & $\begin{array}{l}\text { Picard, } 2002 \\
\text { Zhao et al., } 2011 \\
\text { Schneider et al., } \\
2014\end{array}$ \\
\hline JZ970427 & 274 & $\begin{array}{l}\text { Calmodulin } \\
\text { (CaM) } \\
\text { (calmodulin) }\end{array}$ & $\begin{array}{l}\text { Lymnaea } \\
\text { stagnalis }\end{array}$ & ABB85281.1 & $6 e-11$ & $\begin{array}{l}\text { - Calcium- } \\
\text { activated signal } \\
\text { transduction } \\
- \\
\text { Biomineralisation } \\
\text { - } \\
\text { Phototransduction }\end{array}$ & $\begin{array}{l}\text { Van Eldik et al., } \\
1998 \\
\text { Li et al., } 2004 \\
\text { Hardie, } 2001\end{array}$ \\
\hline \multicolumn{8}{|c|}{ Metabolic function } \\
\hline JZ970420 & 776 & $\begin{array}{l}\text { Pyridoxal } \\
\text { kinase-like } \\
(P D X K)\end{array}$ & Lottia gigantea & XP_009054441.1 & $3 e-117$ & $\begin{array}{l}\text { - Transferase } \\
\text { enzyme involved } \\
\text { in vitamin } \mathrm{B}_{6} \\
\text { metabolism }\end{array}$ & Schibler 2005 \\
\hline \multicolumn{8}{|l|}{ Protein synthesis } \\
\hline N/A & 592 & $\begin{array}{l}\text { 16S } \\
\text { (mitochondrial } \\
\text { rRNA)* }\end{array}$ & M.trossulus & KU925349.1 & 0.0 & $\begin{array}{l}\text { - Mitochondrial } \\
\text { ribosomal } \\
\text { RNA involved } \\
\text { in protein } \\
\text { synthesis }\end{array}$ & Taanman, 1999 \\
\hline
\end{tabular}




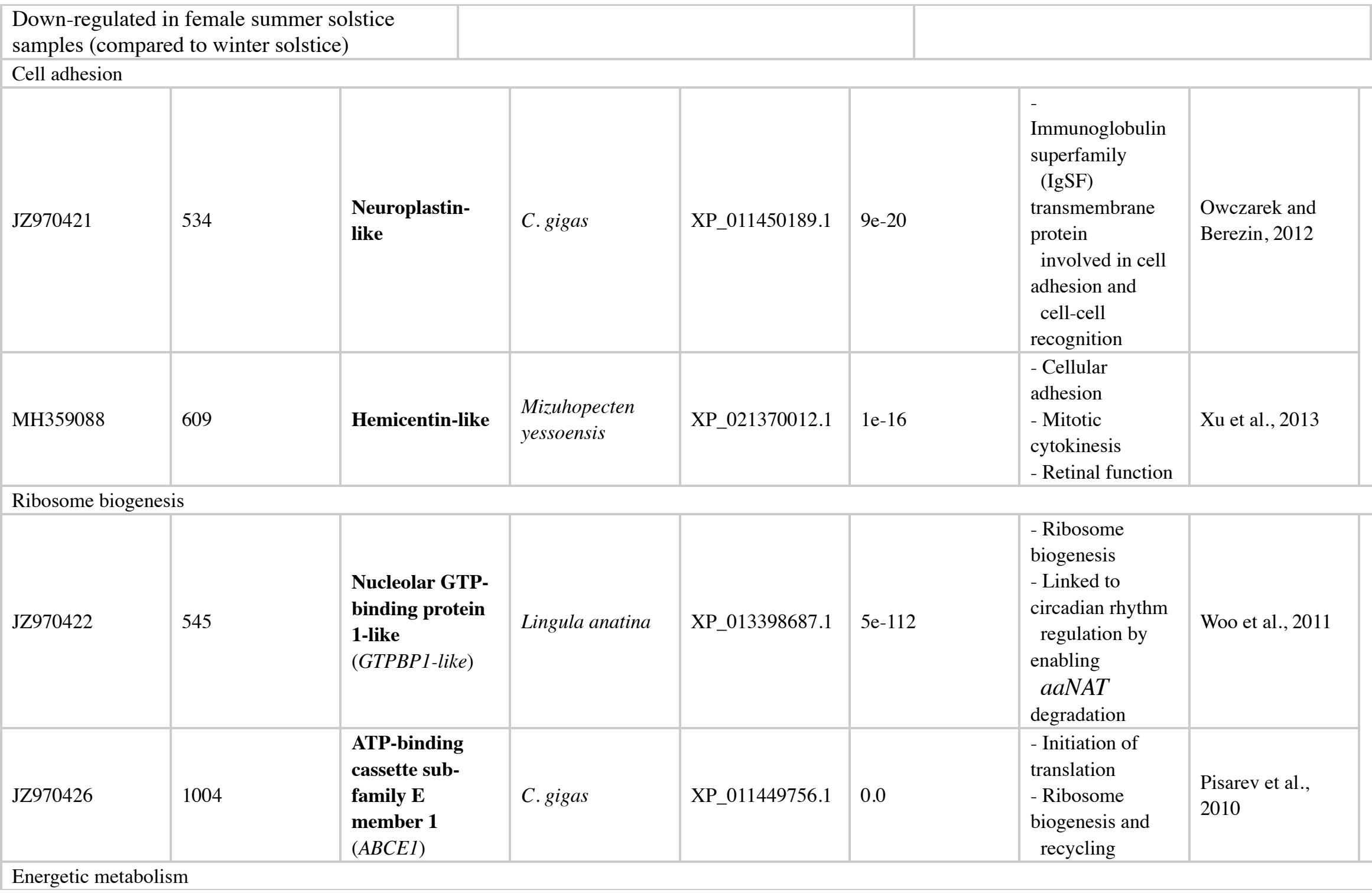




\begin{tabular}{|c|c|c|c|c|c|c|c|}
\hline JZ970423 & 679 & $\begin{array}{l}\text { ATP synthase } \\
\text { lipid-binding } \\
\text { protein, } \\
\text { mitochondrial- } \\
\text { like }\end{array}$ & $\begin{array}{l}\text { Biomphalaria } \\
\text { glabrata }\end{array}$ & XP_013066447.1 & $2 e-41$ & $\begin{array}{l}\text { - Subunit of an } \\
\text { enzyme } \\
\text { catalysing } \\
\text { adenosine } \\
\text { triphosphate } \\
\text { (ATP) synthesis } \\
\text { (Electron } \\
\text { transport chain/ } \\
\text { energy } \\
\text { metabolism) }\end{array}$ & $\begin{array}{l}\text { De Grassi et al., } \\
2006\end{array}$ \\
\hline N/A & 459 & $\begin{array}{l}\text { Cytochrome c } \\
\text { oxidase subunit } \\
\text { II }(C O X 2)\end{array}$ & M. trossulus & ADE05891.1 & $9 e-53$ & $\begin{array}{l}\text { - Subunit of an } \\
\text { enzyme involved } \\
\text { in the } \\
\text { mitochondrial } \\
\text { electron } \\
\text { transport chain/ } \\
\text { energy } \\
\text { metabolism }\end{array}$ & $\begin{array}{l}\text { García-Horsman } \\
\text { et al., } 1994\end{array}$ \\
\hline \multicolumn{8}{|c|}{ Cytoskeleton } \\
\hline JZ970424 & 1033 & $\begin{array}{l}\text { Alpha tubulin } \\
\text { (alpha-tubulin) }\end{array}$ & B. floridae & XP_002601443.1 & 0.0 & $\begin{array}{l}\text { - Microtubule } \\
\text { formation: } \\
\text { - Cytoskeleton } \\
\text { - Chromosome } \\
\text { separation } \\
\text { - Cilia/flagella } \\
\text { structure }\end{array}$ & $\begin{array}{l}\text { Keeling and } \\
\text { Doolittle, } 1996\end{array}$ \\
\hline JZ970428 & 540 & $\begin{array}{l}\text { Centrosomal } \\
\text { protein of } 131 \\
\text { kDa-like (5- } \\
\text { azacytidine } \\
\text { induced protein } \\
\text { 1) } \\
(C E P 131)\end{array}$ & C. gigas & EKC38807.1 & $2 e-16$ & - Cilia formation & Hall et al., 2013 \\
\hline
\end{tabular}




\begin{tabular}{|c|c|c|c|c|c|c|c|}
\hline JZ970425 & 338 & $\begin{array}{l}\text { Mitochondrial- } \\
\text { processing } \\
\text { peptidase } \\
\text { subunit beta-like } \\
(\beta-M P P)\end{array}$ & $\begin{array}{l}\text { Saimiri } \\
\text { boliviensis } \\
\text { boliviensis }\end{array}$ & XP_010349997.1 & $4 e-62$ & $\begin{array}{l}\text { - Subunit of an } \\
\text { enzyme that } \\
\text { cleaves targeting } \\
\text { signals } \\
\text { from } \\
\text { mitochondrial } \\
\text { proteins }\end{array}$ & Gakh et al., 2002 \\
\hline \multicolumn{8}{|l|}{ Metabolism } \\
\hline JZ970429 & 421 & $\begin{array}{l}\text { Chitinase/ } \\
\text { chitotriosidase- } \\
\text { like }\end{array}$ & Mytilus coruscus & AHC08445.2 & $3 e-64$ & $\begin{array}{l}\text { - Enzyme } \\
\text { involved in chitin } \\
\text { metabolism } \\
\text { - } \\
\text { Biomineralisation }\end{array}$ & $\begin{array}{l}\text { Weiss and } \\
\text { Schönitzer, } 2006 \\
\text { Banni et al., } 2011\end{array}$ \\
\hline \multicolumn{8}{|c|}{ Phosphorylation } \\
\hline МH359089 & 724 & $\begin{array}{l}\text { Dual specificity } \\
\text { testis-specific } \\
\text { protein kinase 1- } \\
\text { like } \\
(T E S K 1)\end{array}$ & $\begin{array}{l}\text { Mizuhopecten } \\
\text { yessoensis }\end{array}$ & XP_021367571.1 & $3 e-30$ & $\begin{array}{l}\text { - Phosphorylation } \\
\text { - } \\
\text { Spermatogenesis } \\
\text { role in males }\end{array}$ & Meng et al., 2014 \\
\hline
\end{tabular}

\section{Table 2.}

\begin{tabular}{|c|c|c|c|c|c|c|c|}
\hline $\begin{array}{l}\text { Clone accession } \\
\text { number }\end{array}$ & Length (bp) & Identity & Species match & $\begin{array}{l}\text { Result accession } \\
\text { number }\end{array}$ & e-value & Function & Reference(s) \\
\hline \multicolumn{8}{|c|}{ Up-regulated in male spring equinox samples (compared to winter solstice) } \\
\hline \multicolumn{8}{|c|}{ Energetic metabolism } \\
\hline N/A & 1018 & $\begin{array}{l}\text { NADH } \\
\text { dehydrogenase } \\
\text { subunit } 4 \\
(N D 4)\end{array}$ & M.edulis & AAV68419.1 & $4 e-154$ & $\begin{array}{l}\text { - Mitochondrial } \\
\text { electron } \\
\text { transport chain }\end{array}$ & Craft et al., 2010 \\
\hline \multicolumn{8}{|c|}{ Cytoskeleton organisation } \\
\hline JZ970430 & 328 & $\begin{array}{l}\text { Beta tubulin } \\
\text { (beta-tubulin) }\end{array}$ & $\begin{array}{l}\text { Parascolymia } \\
\text { vitiensis }\end{array}$ & BAD11697.1 & $2 \mathrm{e}-75$ & $\begin{array}{l}\text { - Microtubule } \\
\text { formation: } \\
\text { - Cytoskeleton } \\
\text { - Chromosome } \\
\text { separation } \\
\text { - Cilia/flagella } \\
\text { structure }\end{array}$ & $\begin{array}{l}\text { Keeling and } \\
\text { Doolittle, } 1996\end{array}$ \\
\hline
\end{tabular}




\begin{tabular}{|c|c|c|c|c|c|c|c|}
\hline JZ970431 & 434 & Actin & $\begin{array}{l}\text { Cyrenoida } \\
\text { floridana }\end{array}$ & AAS20336.1 & $1 \mathrm{e}-99$ & $\begin{array}{l}\text { - Microfilament } \\
\text { formation: } \\
\text { - Cytoskeleton } \\
\text { - Cell } \\
\text { contraction } \\
\text { - Cell motility }\end{array}$ & $\begin{array}{l}\text { Mitchison and } \\
\text { Cramer, } 1996\end{array}$ \\
\hline \multicolumn{8}{|c|}{ Down-regulated in male spring equinox samples (compared to winter solstice) } \\
\hline \multicolumn{8}{|c|}{ Protein synthesis } \\
\hline JZ970432 & 979 & $\begin{array}{l}\text { Eukaryotic } \\
\text { Initiation Factor } \\
\text { 4A-like } \\
(e I F-4 A \text {-like })\end{array}$ & C. gigas & XP_011421890.1 & $3 e-142$ & $\begin{array}{l}\text { - Helicase } \\
\text { involved in } \\
\text { protein } \\
\text { synthesis by } \\
\text { binding mRNA to } \\
\text { ribosome }\end{array}$ & $\begin{array}{l}\text { Andreou and } \\
\text { Klostermeier, } \\
2013\end{array}$ \\
\hline \multicolumn{8}{|c|}{ Metabolism } \\
\hline JZ970433 & 915 & $\begin{array}{l}\text { Chitinase/ } \\
\text { chitotriosidase- } \\
\text { like }\end{array}$ & $\begin{array}{l}\text { M. } \\
\text { galloprovincialis }\end{array}$ & AKS48199.1 & $8 \mathrm{e}-84$ & $\begin{array}{l}\text { - Enzyme } \\
\text { involved in chitin } \\
\text { metabolism } \\
\text { - } \\
\text { Biomineralisation }\end{array}$ & $\begin{array}{l}\text { Weiss and } \\
\text { Schönitzer, } 2006 \\
\text { Banni et al., } 2011\end{array}$ \\
\hline
\end{tabular}

